\title{
Pelatihan "INTERAKTIF" Meningkatkan Empati Guru BK
}

\author{
Risa Harisah ${ }^{1}$ E Neila Ramdhani ${ }^{2}$ \\ Fakultas Psikologi Universitas Gadjah Mada
}

\begin{abstract}
The "INTERAKTIF" training was developed to increase the empathy of school counselor in assisting their students. The "INTERAKTIF" module consisted of emotional intelligence and therapeutic communication theory. The research was conducted by untreated control group design method with dependent pretest and posttest samples, which included experimental group and control group. Participants in this reseach consisted of 46 junior high school counselors in Yogyakarta. Statistical analysis result using Mixed ANOVA showed that empathy level on experiment group significantly differed from control group $(F=4.805, p=$ 0.034). The final result showed that the "INTERAKTIF" training effective in increasing the junior high school counselor's empathy in Yogyakarta.
\end{abstract}

Keywords : empathy; emotional intelligence; therapeutic communication

\begin{abstract}
Abstrak. Pelatihan "INTERAKTIF" disusun sebagai salah satu upaya untuk meningkatkan empati guru BK dalam mendampingi siswa. Modul "INTERAKTIF" disusun berdasarkan teori kecerdasan emosi dan komunikasi terapeutik. Penelitian dilakukan dengan metoda untreated control group design with dependent pretest and posttest samples, yaitu penelitian yang menyertakan kelompok eksperimen dan kelompok kontrol. Partisipan dalam penelitian ini adalah 46 guru BK pada tingkat Sekolah Menengah Pertama di Yogyakarta. Hasil analisis statistik menggunakan Mixed ANOVA menunjukkan bahwa tingkat empati pada kelompok eksperimen berbeda secara signifikan dengan kelompok kontrol $(F=4,805, p=0,034)$. Hasil penelitian menunjukkan bahwa pelatihan "INTERAKTIF" efektif dalam meningkatkan empati guru BK SMP di Yogyakarta.
\end{abstract}

Kata kunci : empati; kecerdasan emosi; komunikasi terapeutik

Guru BK masih sering dianggap sebagai "polisi sekolah", guru BK dianggap sebagai petugas penghukum siswa yang bermasalah, yang harus menjaga dan mempertahankan tata tertib, disiplin serta keamanan sekolah. Citra negatif terhadap keberadaan BK sebagai tempat yang tidak nyaman timbul

\footnotetext{
${ }^{1}$ Korespondensi dapat dilakukan melalui: risaharisah@gmail.com

${ }^{2}$ Atau melalui neila_psi@ugm.ac.id
}

dari cara guru BK menangani problema siswa di sekolah (Atamimi, 2010). Guru BK sering ditugaskan untuk mencari siswa yang melanggar aturan dan diberi wewenang untuk menjadi eksekutor bagi siswa-siswa tersebut (Sari, 2010). Layanan BK yang diselenggarakan cenderung pasif dan menekankan pada penyelesaian masalah daripada pencegahan. Siswa jarang diajak berbicara dan difasilitasi untuk menceritakan permasalahan yang dihadapi atau berdialog megenai pikiran dan perasaannya (Atamimi, 
2010). Guru BK masuk kelas hanya untuk memberikan pengumuman atau sosialisasi peraturan (Ramdhani, 2018).

Layanan BK yang belum optimal membuat siswa enggan datang ke BK, padahal siswa membutuhkan dukungan guru BK untuk membantu menghadapi perubahan biologis, kognitif, dan sosioemosional sebagai remaja. Kemampuan adaptasi dan kemampuan berpikir remaja saja tidak cukup membuatnya berhasil terhindar dari dampak negatif perubahan pada diri remaja, remaja membutuhkan dukungan dari orang dewasa. Sementara itu, peran orang tua pada remaja semakin berkurang dan perubahan sosio-emosional remaja mengakibatkan timbulnya konflik dengan orang tua (Santrock, 2010). Permasalahan-permasalahan yang terjadi pada remaja adalah contoh kasus yang mengindikasikan kurangnya layanan bagi siswa untuk berbagi perasaaanya (Ramdhani, 2012). Di Yogyakarta, kenakalan remaja dinilai sebagai salah satu hal yang berpotensi mengancam keamanan dan ketertiban umum karena telah merambah menjadi kriminalitas remaja (Kur, 2016).

Kurangnya layanan BK dalam memfasilitasi siswa dalam berdialog kemungkinan disebabkan oleh minimnya kemampuan guru BK untuk membuat siswa nyaman untuk terbuka dalam menceritakan isi hati dan pikirannya. Hal ini sesuai dengan hasil penelitian Wardhani (2009) yang menemukan bahwa guru BK belum mampu membuat siswa nyaman untuk berbagi perasaaannya, guru BK belum berhasil membuat siswa terlibat dan terbuka untuk mengungkapkan pikiran, perasaan maupun gagasannya, bahkan guru BK cenderung bersikap defensif. Keterampilan konseling serta kualitas pribadi guru BK dalam melaksanakan hubungan konseling belum efektif menunjang tercapainya tujuan hubungan konseling.
Guru BK seharusnya mampu menyelenggarakan layanan $\mathrm{BK}$ dengan optimal, yaitu pendampingan yang dapat membantu siswa untuk beradaptasi dengan perubahan sebagai remaja, mampu mengembangkan potensinya, dan mampu mengambil keputusan secara mandiri dalam berbagai aspek. Hal tersebut sebagaimana tercantum dalam Peraturan Menteri Pendidikan dan Kebudayaan nomor 111 tahun 2014 dan Peraturan Menteri Pendidikan Nasional nomor 27 tahun 2008 mengenai tujuan layanan BK. Agar dapat mendampingi siswa dengan optimal, Guru BK perlu memiliki kompetensi tertentu, yaitu (1) memahami secara mendalam konseli yang dilayani, (2) menguasai landasan dan kerangka teoretik bimbingan dan konseling, (3) menyelenggarakan pelayanan bimbingan dan konseling yang memandirikan, dan (4) mengembangkan pribadi dan profesionalitas konselor secara berkelanjutan. Kompetensi tersebut dirumuskan dalam empat kompetensi, yaitu kompetensi personal, kompetensi sosial, kompetensi penunjang (dalam lingkungan pendidikan disebut kompetensi pedagogik), dan kompetensi akademik (Permen Diknas nomor 27 tahun 2008).

Kompetensi personal, sosial, dan penunjang dapat dirumuskan dalam keterampilan psikologis, diantaranya social awareness atau empati, komunikasi, selfawareness, self-motivation, self-regulation, dan lain-lain. Profesi sebagai guru BK membutuhkan keterampilan khusus dalam berhubungan dengan orang lain, maka di antara keterampilan psikologis yang disebutkan, kesadaran akan lingkungan sosial merupakan hal yang utama. Kesadaran sosial yang baik menjadi dasar bagi seseorang untuk dapat menjalin komunikasi dengan efektif. Kesadaran sosial atau disebut juga empati adalah kesadaran akan perasaan, kebutuhan, dan kepertingan orang lain (Goleman, 1998). Empati adalah kemampuan 
pengambilan perspektif sosial yang melibatkan pemahaman kognitif terhadap perasaan-perasaan dan motif-motif orang lain (Davis, 1983). Empati membuat seseorang dapat memahami kebutuhan orang lain sehingga dapat menampilkan respon yang tepat ketika berkomunikasi dengan orang lain. Abdolvahabi, Bagheri, Haghighi, Karimi (2012) mengatakan bahwa orang yang memiliki empati mampu menyadari kebutuhan atau permintaan orang lain dengan sedikit saja sinyal yang ditunjukkan oleh orang tersebut.

Empati yang ditunjukkan guru BK akan membuat siswa merasa dimengerti, sehingga empati perlu dimiliki guru BK dalam mendampingi siswa, terutama dalam pelaksanaan konseling. Penelitian Hakansson dan Montgomery (2003) menemukan bahwa empati dalam konteks interpersonal membuat lawan bicara (dalam konteks ini klien) mendapatkan konsekuensi positif. Konsekuensi positif tersebut berupa perasaan dimengerti, merasa terbantu, dan mendapat dukungan. DePue dan Lambie (2014) menyebutkan bahwa tingkat kompetensi konselor terkait dengan kemampuan mereka untuk bersikap empati. Jika konselor memahami klien mereka pada tingkat kognitif dan afektif mengenai perasaan sedih mereka, maka mereka dapat secara akurat merefleksikan perasaan dan makna di balik pengalaman klien. Hal ini didukung oleh pernyataan Clark (2007), bahwa empati potensial untuk meningkatkan client understanding, hubungan selama treatment, dan proses terapeutik. Ioannidou dan Konstantikaki (2008) juga menjelaskan bahwa komunikasi empatik yang efektif dapat meningkatkan efektivitas hubungan terapeutik antara konselor dan klien. Penggunaan empati yang tepat dapat dijadikan alat komunikasi yang memudahkan wawancara klinis dan meningkatkan efisiensi pengumpulan informasi.
Guru BK perlu meningkatkan empatinya agar lebih optimal dalam mendampingi siswa. Empati dapat ditingkatkan melalui beberapa cara, diantaranya pelatihan, praktikum, dan penyuluhan. Berkhout dan Malouff (2016) menemukan hasil yang konsisten pada 19 penelitian bahwa pelatihan efektif dalam meningkatkan empati. Hasil yang sama juga ditemukan oleh Lam, Kolomitro, dan Alamparambil (2011) serta Riess, Kelley, Bailey, Dunn, dan Phillips (2012). Penelitian mengenai program peningkatan empati juga telah dilakukan oleh beberapa peneliti dari Universitas Gadjah Mada, Aziza (2015) dan Saleh (2008) juga menunjukkan adanya pengaruh pelatihan terhadap peningkatan empati. Sulistyaningsih (2009) menemukan bahwa penyuluhan dan pelatihan dapat meningkatkan empati guru Sekolah Dasar di Kabupaten Aceh Selatan. Selain pelatihan dan penyuluhan, DePue dan Lambie (2014) menemukan bahwa empati dapat ditingkatkan melalui praktikum yang diikuti oleh calon konselor.

Ioannidou \& Konstantikaki (2008) menyatakan bahwa empati merupakan ciri utama dari kecerdasan emosi. Hal ini sesuai dengan pernyataan Goleman (1998), bahwa empati adalah salah satu elemen dalam kecerdasan emosi yang saling berhubungan dengan elemen-elemen lainnya. Penelitian Johnson (2016) menemukan bahwa kemampuan dalam kecerdasan emosi memengaruhi kemampuan praktisi untuk berkomunikasi secara profesional, menunjukkan empati, mendapatkan kepercayaan dari klien, dan mempromosikan perubahan gaya hidup yang berkelanjutan di masyarakat. Selain kecerdasan emosi, Altmann, Schonefeld, dan Roth, (2015) menyebutkan bahwa konsep Non-Violence Communication (NVC) atau komunikasi terapeutik dapat digunakan sebagai teknik yang sangat membantu untuk belajar dan berlatih ekspresi dan refleksi dari empati. 
Oleh karena itu, modul pelatihan dalam penelitian ini disusun berdasarkan teori kecerdasan emosi dan konsep NVC dan dinamakan "INTERAKTIF".

"INTERAKTIF" merupakan akronim dari inisiatif, terampil, dan komunikatif. Inisiatif mewakili kompetensi personal guru dan komunikatif mewakili kompetensi sosial, kedua kompetensi ini disusun berdasarkan teori kecerdasan emosi dari Goleman (1998). Terampil mewakili kompetensi penunjang, yang disusun berdasarkan konsep NVC dari Rossenberg (2005). Modul pelatihan "INTERAKTIF" mengacu pada modul pelatihan "ASPIRASI" yang disusun oleh Aziza (2015) dan modul pelatihan "Pelatihan Keterampilan Dasar Konseling (PKDK)" yang disusun oleh Hervina (2017). Kedua modul tersebut memodifikasi modul Teacher Quality Improvement (TQI) yang disusun oleh Titian Foundation.

Tujuan dari penelitian ini adalah untuk menguji pengaruh modul pelatihan "INTERAKTIF" untuk meningkatkan empati guru BK Sekolah Menengah Pertama di Yogyakarta.

Pelatihan yang dilakukan didasarkan pada pelatihan keterampilan psikologis berdasarkan teori Goldstein (1981) dan metode experiential learning berdasarkan teori Kolb dan Kolb (2009). Metode experiential learning terbukti meningkatkan empati siswa yang memiliki empati rendah dalam berinteraksi sosial (Wulandari, Setyowati, dan Mugiarso, 2012). Vanlaere, Coucke, dan Gastmans (2010) juga berhasil menggunakan metode ini untuk mengajarkan kepedulian yang mencerminkan kepemilikan rasa empati pada profesi di bidang layanan masyarakat.

\section{Metode}

Variabel tergantung dalam penelitian ini adalah empati, dan variabel bebas adalah pelatihan "INTERAKTIF. Definisi operasional dari empati adalah kemampuan guru BK untuk memahami pikiran dan perasaan siswa dengan menempatkan diri pada posisi siswa. Empati guru BK dalam mendampingi siswa dapat dilihat dari kemampuannya dalam melihat suatu situasi atau permasalahan dari perspektif siswa, membayangkan berada dalam posisi siswa, mendahulukan kepentingan siswa, dan menyelesaikan masalah pribadi. Modul pelatihan "INTERAKTIF" disusun berdasarkan teori kecerdasan emosi dari Goleman (1998) dan konsep Non Violence Communication dari Rossenberg (2005). Modul tersebut berisi tiga kompetensi, yaitu kompetensi personal, kompetensi sosial, dan kompetensi penunjang yang disajikan dalam sepuluh sesi dan diselenggarakan dalam 3 hari.

Empati guru BK dilihat melalui skor skala empati yang dikembangkan dari skala Interpersonal Reactivity Index (IRI) milik Davis (1983). Penelitian juga menyertakan skala kecerdasan emosi konselor yang disusun berdasarkan kerangka modul "INTERAKTIF" untuk melihat efektivitas pelatihan terhadap peningkatan empati.

Penelitian ini merupakan penelitian eksperimen kuasi, dengan tujuan menguji pengaruh pelatihan "INTERAKTIF" terhadap peningkatan empati guru BK. Desain penelitian menggunakan untreated control group design with dependen pretest and posttest samples. Penelitian dengan desain ini menggunakan dua kelompok, yaitu kelompok yang diberikan perlakuan dan kelompok yang tidak diberi perlakuan sebagai kelompok pembanding, kedua kelompok diberikan pretest dan posttest (Shadish, Cook, \& Campbell, 2002). Desain penelitian pada Gambar 1 .

Partisipan dalam penelitian ini adalah 60 guru BK dengan karakteristik bekerja di Sekolah Menengah Pertama (SMP), bekerja rendah (skor pretest). Berdasarkan karakteristik partisipan tersebut 
dapat disimpulkan bahwa pemilihan partisipan penelitian menggunakan teknik puposive sampling. Pengelompokkan partisipan ke dalam kelompok eksperimen dan kelompok kontrol menggunakan teknik matching dengan mengurutkan skor atau disebut rank-order matching (Myers \& Hansen, 2012). Pada penelitian ini, partisipan diurutkan berdasarkan skor empatinya, kemudian dibuat pasangan berdasarkan urutan tersebut dan dilakukan randomisasi untuk memasukkannya ke dalam kelompok eksperimen dan kelompok kontrol.

$\begin{array}{llll}N R & \text { O1 } & X & \text { O2 } \\ N R & \text { O1 } & & \text { O2 }\end{array}$

Gambar 1. Desain penelitian

Keterangan :

O1: Pengukuran pretest tingkat empati partisipan.

\section{X : Pelatihan "INTERAKTIF" sebagai perlakuan.}

O2: Pengukuran posttest tingkat empati partisipan.

Teknik analisis statistik yang digunakan adalah Mixed ANOVA, karena desain penelitian mengkombinasikan desain within-subject design dan between-subject design dalam satu eksperimen. Mixed ANOVA yaitu analisis yang mengeksplorasi skor rata-rata variabel tergantung antara satu atau lebih within-group independent variables dan satu atau lebih between-group independent variables (Mayers, 2013; Myers \& Hansen, 2012).

\section{Hasil}

Statistika deskriptif

Tabel 1.

Mean Skor Empati

\begin{tabular}{lccc}
\hline & Pre-test & $\begin{array}{c}\text { Post- } \\
\text { test }\end{array}$ & $\begin{array}{c}\text { Selisih } \\
\text { Mean }\end{array}$ \\
\hline $\begin{array}{l}\text { Kelompok } \\
\text { Eksperimen }\end{array}$ & 80,83 & 84,74 & 3,913 \\
\hline $\begin{array}{l}\text { Kelompok } \\
\text { Kontrol }\end{array}$ & 80,13 & 80,17 & 0,043 \\
\hline
\end{tabular}

Tabel 2.

Mean Skor Kecerdasan Emosi Konselor

\begin{tabular}{lccc} 
& Pre-test & $\begin{array}{c}\text { Post- } \\
\text { test }\end{array}$ & $\begin{array}{c}\text { Gain } \\
\text { score }\end{array}$ \\
\hline $\begin{array}{l}\text { Kelompok } \\
\text { Eksperimen }\end{array}$ & 77,13 & 80,78 & 3,652 \\
\hline $\begin{array}{l}\text { Kelompok } \\
\text { Kontrol }\end{array}$ & 78,48 & 76,91 & 1,565 \\
\hline
\end{tabular}

Uji asumsi

Hasil uji normalitas menggunakan ShapiroWink test menunjukkan bahwa nilai $\mathrm{z}$ kelompok eksperimen sebesar 0,955 dengan nilai signifikansi 0,374 ( $p>0,05)$, dan nilai $\mathrm{z}$ kelompok kontrol sebesar 0,924 dengan nilai signifikansi 0,080 ( $p>0,05)$ (Lampiran 27). Hal tersebut mengindikasikan data berdistribusi normal.

Hasil Uji homogenitas antar kelompok (between-group) yang dilakukan dengan Levene's Test menunjukkan bahwa nilai signifikansi sebelum dan setelah perlakuan lebih dari 0,05. Uji homogenitas within-group pada kelompok ekperimen dan kelompok kontrol dengan Box's test menunjukkan nilai signifikansi sebesar 0,641 ( $\mathrm{p}>0,001)$. Maka, dapat disimpulkan bahwa data homogen atau terdapat korelasi pada skor empati sebelum dan setelah perlakuan pada kedua kelompok.

Uji hipotesis

Hasil pengujian hipotesis dengan menggunakan Mixed ANOVA pada skor empati menunjukkan bahwa nilai $F=4,805$ 
dan nilai signifikansi $0,034(p<0,05)$. Artinya terdapat interaksi antara time (pretest dan posttest) dan group (kelompok eksperimen dan kelompok kontrol). Interaksi menunjukkan bahwa terdapat perbedaan yang signifikan antara skor empati sebelum dan sesudah pelatihan pada salah satu kelompok. Analisis lanjutan untuk melihat interaksinya dapat dilihat pada Tabel 3.

Tabel 3.

Analisis Lanjutan Skor Empati

\begin{tabular}{ccc}
\hline Kelompok & Sig. & $\begin{array}{c}\text { Partial Eta } \\
\text { Squared }\end{array}$ \\
\hline Eksperimen & $0,003(\mathrm{p}<0,05)$ & 0,183 \\
\hline Kontrol & $0,972(\mathrm{p}>0,05)$ & 0,000 \\
\hline
\end{tabular}

Berdasarkan Tabel 3, diketahui bahwa terdapat perubahan yang signifikan antara skor empati sebelum dan setelah pelatihan pada kelompok eksperimen, namun tidak terdapat perubahan yang signifikan antara skor empati sebelum dan setelah pelatihan pada kelompok kontrol. Oleh karena itu, dapat disimpulkan bahwa pelatihan "INTERAKTIF" yang diberikan pada kelompok eksperimen cukup efektif dalam meningkatkan empati partisipan. Sumbangan efektif pelatihan "INTERAKTIF" terhadap peningkatan empati adalah sebesar $18,3 \%$.

Mixed ANOVA juga digunakan untuk membandingkan hasil pengukuran pada skala kecerdasan emosi konselor antara pretest dan postest. Berdasarkan hasil analisis, diketahui bahwa $\mathrm{F}=7,778$ dan $\mathrm{p}=0,008$ $(\mathrm{p}<0,05)$. Artinya terdapat interaksi antara time (pretest dan posttest) dan group (kelompok eksperimen dan kelompok kontrol). Interaksi menunjukkan bahwa terdapat perbedaan yang signifikan antara skor sebelum dan sesudah pelatihan pada kelompok eksperimen dan kelompok kontrol (Widhiarso, 2011). Oleh karena itu, analisis statistik dilanjutkan dengan tabel 4 untuk melihat interaksinya dengan lebih spesifik.
Tabel 4.

Analisis Lanjutan Skor Kecerdasan Emosi Konselor

\begin{tabular}{ccc}
\hline Kelompok & Sig. & $\begin{array}{c}\text { Partial Eta } \\
\text { Squared }\end{array}$ \\
\hline Eksperimen & $0,008(\mathrm{p}<0,05)$ & 0,148 \\
\hline Kontrol & $0,243(\mathrm{p}>0,05)$ & 0,031 \\
\hline
\end{tabular}

Berdasarkan tabel 4, diketahui bahwa terdapat perubahan yang signifikan antara skor kecerdasan emosi konselor sebelum dan setelah pelatihan pada kelompok eksperimen, namun tidak terdapat perubahan yang signifikan antara skor kecerdasan emosi konselor sebelum dan setelah pelatihan pada kelompok kontrol. Oleh karena itu, dapat disimpulkan bahwa pelatihan "INTERAKTIF" yang diberikan pada kelompok eksperimen efektif dalam meningkatkan kecerdasan emosi konselor partisipan.

\section{Diskusi}

Hipotesis dalam penelitian ini adalah pelatihan "INTERAKTIF" dapat meningkatkan empati guru BK SMP dalam mendampingi siswa. Berdasarkan hasil uji hipotesis dengan menggunakan ANOVA Mixed Design, diperoleh nilai $F=4,805$ dan nilai signifikansi 0,034 $(p<0,05)$. Artinya, terdapat interaksi antara skor sebelum pelatihan dan skor setelah pelatihan pada kelompok eksperimen dan kelompok kontrol. Berdasarkan uji lanjutan, diketahui bahwa terdapat peningkatan mean empati sebelum dan setelah pelatihan pada kelompok eksperimen sebesar 3,913 poin dengan nilai signifikansi $0,003(p<0,05)$, namun tidak terdapat peningkatan mean empati pada kelompok kontrol (perbedaan mean 0,043 dengan nilai signifikansi 0,972). Hasil tersebut menunjukkan bahwa terdapat perubahan yang signifikan antara skor empati sebelum dan setelah pelatihan pada kelompok eksperimen, namun tidak terdapat 
perubahan yang signifikan antara skor empati sebelum dan setelah pelatihan pada kelompok kontrol. Oleh karena itu, dapat disimpulkan bahwa pelatihan "INTERAKTIF" yang diberikan pada kelompok eksperimen cukup efektif dalam meningkatkan empati partisipan, dengan sumbangan efektif sebesar 18,3 \%. Pemaparan tersebut menunjukkan bahwa hipotesis diterima.

Selain itu, diperoleh nilai $F=7,778$ dengan nilai signifikansi 0,008 $(p<0,05)$ pada skor kecerdasan emosi konselor sebelum dan sesudah pelatihan pada kelompok eksperimen dan kelompok kontrol. Pada kelompok eksperimen, mean kecerdasan emosi konselor sebelum dan setelah pelatihan meningkat sebesar 3,652 poin dengan uji signifikansi $0,008 \quad(p<0,05)$, sedangkan mean kecerdasan emosi konselor pada kelompok kontrol justru menurun sebesar 1,565 dengan nilai signifikansi 243 $(p>0,05)$. Hal ini menunjukkan bahwa peningkatan empati pada partisipan disebabkan oleh pelatihan yang telah diberikan.

Hasil uji statistika juga didukung oleh data hasil observasi para observer selama pelaksanaan program dan refleksi peserta terhadap pembelajaran yang diperoleh setiap sesi. Persentase rata-rata pada keterlibatan masing-masing subjek berkisar antara $60,16 \%-95,83 \%$ dengan rata-rata keterlibatan seluruh subjek $79,03 \%$. Hal ini menunjukkan bahwa partisipan pelatihan terlibat aktif dalam mengemukakan pendapat dalam sesi materi maupun diskusi kelompok, partisipan juga terlihat mendengarkan dan memperhatikan penjelasan atau instruksi, serta melaksanakan tugas dengan baik. Pemerolehan pembelajaran partisipan dalam setiap sesi pelatihan juga diukur secara kualitatif. Hasilnya, sebagian besar partisipan memperoleh pembelajaran yang sesuai dengan tujuan setiap sesinya. Beberapa partisipan yang dinilai oleh observer dapat mengikuti pelatihan dengan antusias dan terlibat aktif dalam proses pelatihan, partisipan tersebut juga dapat menerima pembelajaran sesuai dengan tujuan setiap sesinya, sehingga mengalami peningkatan skor kecerdasan emosi konselor dan skor empati.

Keberhasilan pelatihan yang telah dicapai dalam penelitian ini mendukung beberapa penelitian sebelumnya yang menemukan bahwa empati dapat ditingkatkan melalui pelatihan, salah satunya penelitian yang dilakukan Riess, et al. (2012) terhadap dokter. Hasil penelitian juga selaras dengan meta-analisis yang dilakukan oleh Berkhout dan Malouff (2016) serta meta-analisis yang dilakukan Lam, Kolomitro, dan Alamparambil (2011). 19 penelitian yang dikaji Berkhout dan Malouff (2016) menemukan bahwa seluruh empati dapat ditingkatkan melalui beberapa program imtervensi. 27 penelitian dari 29 penelitian yang dikaji Lam, Kolomitro, dan Alamparambil (2011) menunjukkan bahwa empati dapat ditingkatkan dengan pelatihan.

Gain score empati partisipan menunjukkan peningkatan empati pada kelompok eksperimen bervariasi, dengan rentang angka -5 sampai 16 . Beberapa partisipan mengalami peningkatan skor yang cukup tinggi namun adapun partisipan yang mengalami penurunan skor. Partisipan SO, SM, dan SD engalami peningkatan skor empati yang cukup tinggi berdasarkan data lain, yaitu observasi, kepuasan dan refleksi. Partisipan SO (Laki-laki, 49 tahun) mengalami peningkatan skor empati sebesar 16 poin. Berdasarkan hasil observasi, SO terlihat antusias memperhatikan penjelasan dan instruksi dari trainer, SO juga mengerjakan tugas-tugas selama pelatihan dengan sangat baik, dan SO bersedia memberikan pendapat ketika diberikan kesempatan oleh trainer. Hasil refleksi juga menunjukkan bahwa SO mampu menangkap pembelajaran-pembelajaran di setiap sesi dengan tepat. 
Partisipan SM (Perempuan, 37 tahun) mengalami peningkatan skor empati sebesar 13 poin. SM menilai bahwa pelatihan "INTERAKTIF" memuaskan, kemungkinan hal tersebut yang membuat SM antusias dalam mengikuti aktivitas pelatihan dan menghayati setiap pembelajaran yang diperoleh dari pelatihan, sehingga SM mampu menghayati dan memperoleh pembelajaran yang sangat baik dari setiap sesi pelatihan. Hal tersebut ditunjukkan dari refleksi yang ditulis oleh SM, SM juga menuliskan beberapa hal yang akan ia perbaiki setelah mengikuti pelatihan, berikut salah satu refleksi SM, yaitu refleksi mengenai sesi komunikasi terapeutik:

“...Komunikasi terapeutik untuk berubah lebih baik setelah mengikuti diklat. Kita menggunakan empati untuk memahami perasaan siswa didik kita dengan membayangkan apabila kita berada di posisi siswa tersebut, sehingga kita bisa membantu permasalahan siswa dengan baik."

Partisipan SD (Perempuan, 52 tahun) mengalami peningkatan skor empati sebesar 13 poin. Kepuasan SD terhadap pelatihan memang rata-rata, keterlibatannya dalam proses pelatihan pun rata-rata, SD memperhatikan pemaparan materi maupun diskusi namun kurang aktif berpendapat. Meskipun demikian, SD mampu menangkap pembelajaran setiap sesi dengan tepat sesuai dengan tujuan sesi. Dilihat dari refleksi yang dituliskan, SD mampu menganalisa apa yang diperoleh di dalam ruang pelatihan dan mengintegrasikan dengan perannya sebagai guru BK, sehingga mampu menetapkan tujuan atau rencana pendampingan terhadap siswa yang akan dilakukan setelah pelatihan. Misalnya, refleksi pada sesi mengenal dan memahami orang lain, SD menuliskan :

"Dapat mengetahui kelebihan dan kelemahan yang ada pada orang lain, bermanfaat sebagai guru BK untuk memahami siswa sehingga dapat memberikan bantuan yang tepat."
Meskipun pelatihan"INTERAKTIF" secara signifikan dapat meningkatkan empati, namun terdapat partisipan yang mengalami penurunan skor empati. Berdasarkan skor kecerdasan emosi konselor partisipan, data observasi, kepuasan dan refleksi. diperoleh penjelasan penurunan skor empati masing-masing peserta.

\section{Partisipan EN}

Partisipan EN (Perempuan, 24 tahun) mengalami penurunan skor empati sebesar 5 poin. Berdasarkan observasi yang dilakukan observer, EN dinilai kurang terlibat dalam sesi materi atau diskusi kelompok besar yang dipimpin oleh trainer. EN beberapa kali terlihat tidak fokus dan sering bermain handphone saat proses pelatihan, EN juga terlihat meninggalkan ruangan ketika sesi III sedang berlangsung. Kurangnya keterlibatan dan atusiasme EN dalam mengikuti proses pelatihan kemungkinan membuat EN kurang mampu memperoleh pembelajaran yang tepat, yang tercermin dalam penurunan skor kecerdasan emosi konselor EN. Hal ini didukung oleh data refleksi yang ditulis EN, EN memperoleh pembelajaran yang kurang tepat dalam beberapa sesi, misalnya dalam sesi pandangan terhadap siswa EN menuliskan :

"Dapat memiliki keterampilan-keterampilan lain; sebagai guru harus belajar; sebagai guru tidak boleh egois terhadap siswa."

\section{Partisipan SA}

Partisipan SA (Laki-laki, 55 tahun) mengalami penurunan skor empati sebesar 5 poin. Hasil observasi menunjukkan bahwa antusiasme dan keterlibatan SA dalam pelatihan cukup rendah, SA beberapa kali terlihat tidak fokus mengikuti proses pelatihan. Meskipun kepuasan SA terhadap pelatihan terbilang tinggi, namun rendahnya antusiasme dan keterlibatan SA terhadap aktivitas pelatihan membuat SA kurang mampu memperoleh pembelajaran yang tepat dari pelatihan. Hal tersebut terlihat dari 
adanya penurunan skor kecerdasan emosi konselor dan refleksi yang ditulis SA. Berikut salah satu pembelajaran yang kurang sesuai yang dituliskan SA dari sesi motivasi diri dan sesi memahami diri:

"Kita harus fokus pada masalah; kita harus teliti"

"Kita dapat memperoleh pengalaman bahwa kita masih banyak kekurangan yang harus kita perbaiki; kita membantu teman-teman yang perlu mendapat bantuan."

\section{Partisipan SP}

Partisipan SP (Laki-laki, 45 tahun) mengalami penurunan skor empati sebesar 4 poin. Hasil observasi menyebutkan bahwa SP menunjukkan kurangnya antusiasme dalam mengikuti pelatihan. SP terlihat beberapa kali terlambat datang, baik di pagi hari maupun setelah jam istirahat, bahkan SP sama sekali tidak mengikuti sesi $X$. Kurangnya antusiasme SP membuat SP tidak mampu menangkap pembelajaran dari pelatihan secara menyeluruh. Hal ini terlihat dari penurunan skor kecerdasan emosi konselor SP dan dari lembar refleksi SP, SP tidak menuliskan refleksi untuk sesi VIII, SP juga menuliskan pembelajaran yang kurang tepat pada sesi memahami keberagaman, yaitu :

"Kita harus konsentrasi dan teliti dalam menangani segala sesuatu."

\section{Partisipan SR}

Partisipan SR (Perempuan, 58 tahun) mengalami penurunan skor empati sebesar 4 poin, padahal SR terlihat cukup antusias dalam aktivitas pelatihan. Berdasarkan lembar reaksi SR merasa kurang puas pada pelatihan, kemungkinan persentase kepuasan SR yang berada di bawah rata-rata mempengaruhi motivasi SR dalam mengikuti aktivitas dalam pelatihan. Oleh karena itu, dilihat dari skor kecerdasan emosi konselor SR yang menurun dan beberapa refelsi yang ditulis oleh SR, dapat disimpulkan bahwa tidak semua pembelajaran dari pelatihan dapat diterima oleh SR. Contohnya, SR hanya menuliskan kalimat berikut untuk refleksi sesi kreativitas dalam mengelola keberagaman, komunikasi terapeutik, dan roleplay:

"Saya mendapatkan pengetahuan baru"

"Dapat menerapkan di sekolah dalam pembimbingan kepada siswa, juga dapat lebih bisa memahami siswa."

"Saya senang dapat praktek konseling, berarti dalam PLPG."

Berdasarkan pemaparan mengenai beberapa partisipan yang mengalami peningkatan skor empati yang cukup tinggi dan partisipan yang mengalami penurunan, dapat disimpulkan bahwa terdapat variabel yang menengahi atau menjadi moderator antara pelatihan yang diselenggarakan dengan perubahan skor empati. Berkhout dan Malouff (2016) menemukan empat variabel yang secara signifikan menjadi moderator antara program pelatihan dengan peningkatan empati, yaitu karakteristik partisipan, kompensasi, cakupan pengukuran empati, dan alat ukur empati. Variabel yang paling memungkinkan menjadi moderator peningkatan skor empati dalam penelitian ini adalah karakteristik partisipan, karena kompensasi, cakupan pengukuran empati, dan alat ukur empati sudah dikontrol.

Studi yang dilakukan Lam, Kolomitro, dan Alamparambil (2011) terhadap 29 penelitian menemukan bahwa peningkatan empati dimoderatori oleh jenis kelamin, usia, tingkat pendidikan, dan waktu pengukuran. Barone, et al. (2005) menemukan bahwa terdapat perbedaan skor empati antara lakilaki dan perempuan setelah diberikan suatu program latihan dan pemberian umpan balik. Hal ini juga ditemukan dalam penelitian Fernandez-Olano, MontoyaFernandez, dan Salinas-Sanchez (2008), bahwa skor empati perempuan lebih tinggi daripada laki-laki. Pada penelitian ini, terdapat 6 partisipan yang mengalami 
peningkatan empati lebih dari 10 poin, 4 orang perempuan (CR, SK, SM dan SD) dan 2 orang laki-laki (AG dan SO). Partisipan yang mengalami penurunan skor empati berjumlah 5 orang, 2 orang perempuan (EN dan $\mathrm{WN}$ ) dan 3 orang laki-laki (SJ, SP dan SA). Apabila melihat perbandingan jenis kelamin partisipan dengan perubahan skor empati, partisipan yang mengalami penurunan skor empati memang lebih banyak laki-laki, namun hal ini belum bisa disimpulkan mengingat jumlah partisipan perempuan dan laki-laki tidak seimbang dan tidak dilakukan analisis secara menyeluruh terhadap semua partisipan. Oleh karena itu, terdapat kemungkinan bahwa variabel jenis kelamin menjadi salah satu penyebab terdapatnya perubahan skor empati yang berbeda pada partisipan, namun perlu diadakan penelitian lebih lanjut mengenai hal tersebut.

Selain jenis kelamin, Lam, Kolomitro, dan Alamparambil (2011) juga menyebutkan bahwa usia dan tingkat pendidikan menjadi moderator antara keberhasilan suatu program dalam meningkatkan empati. Hal ini dijelaskan oleh Ancel (2006) bahwa terdapat perbedaan skor empati yang signifikan antara kelompok usia dan kelompok pendidikan yang berbeda. Kelompok usia dengan rentang 25 sampai 30 tahun menunjukkan peningkatan empati yang lebih tinggi daripada kelompok usia yang lebih muda atau yang lebih tua. Selain itu, kelompok partisipan dengan pendidikan sarjana mengalami peningkatan skor empati lebih tinggi daripada partisipan yang belum sarjana (Ancel, 2006). Peneilitian ini tidak mengontrol usia, usia partisipan berkisar antara 24 tahun sampai 59 tahun, sedangkan tingkat pendidikan semua partisipan minimal sarjana. Jika melihat usia partisipan pada data demografi partisipan (Lampiran 19), diketahui bahwa EN yang mengalami penurunan empati paling tinggi berusia 24 tahun $(<25$ tahun), sedangkan yang lainnya berada di atas usia 30 tahun. Oleh karena itu, terdapat kemungkinan bahwa usia menjadi mediator dalam keberhasilan suatu program dalam meningkatkan empati, namun sama seperti variabel jenis kelamin bahwa hal ini perlu diteliti lebih lanjut.

Selain karakteristik dari partisipan seperti yang telah dijelaskan, perubahan skor yang bervariasi juga kemungkinan disebabkan oleh motivasi partisipan mengikuti pelatihan. Hal ini sesuai dengan pernyataan Afiatin, Sonjaya, dan Pertiwi (2013) yang menyebutkan bahwa kesiapan peserta pelatihan merupakan salah satu aspek yang mempengaruhi keberhasilan pelatihan, selain aspek lain seperti struktur program pelatihan, transfer pelatihan, dan penghargaan terhadap hasil pelatihan. Kesiapan peserta meliputi sikap dan motivasi peserta selama mengikuti pelatihan, sikap dan motivasi yang positif terhadap program pelatihan merupakan unsur yang sangat penting dalam menunjang keberhasilan program pelatihan (Afiatin, Sonjaya, \& Pertiwi, 2013). Berdasarkan hasil observasi dari observer, serta evaluasi (reaction sheet) dari partisipan diketahui bahwa sebagian besar partisipan yang mengalami penurunan skor empati terlihat kurang antusias dan tidak terlibat aktif dalam aktivitas pelatihan, adapula partisipan yang menilai pelatihan kurang memuaskan. Oleh karena itu, dapat disimpulkan bahwa karakteristik partisipan yang paling memungkinkan menjadi hal yang berpengaruh pada perubahan skor empati dalam penelitian ini adalah kesiapan peserta, yaitu motivasi dan sikap peserta terhadap pelatihan.

Salah satu hal yang berpotensi menjadi penyebab kurangnya antusiasme dan motivasi beberapa partisipan dalam mengikuti pelatihan "INTERAKTIF" adalah tidak adanya program "Buy $I n$ " di awal, sebagaimana program TQI. Apabila dibandingkan dengan program TQI, pelatihan "INTERAKTIF" merupakan bagian dari rangkaian program yang idealnya 
diawali dengan program "Buy In" dan ditindaklanjuti dengan program pendampingan. Tidak adanya program "Buy In" membuat kurangnya dukungan dari Kepala Sekolah yang kemungkinan berpengaruh terhadap antusiasme dan motivasi partisipan dalam mengikuti pelatihan. Tidak adanya program pendampingan membuat proses pengaplikasian keterampilan yang diperoleh dari pelatihan menjadi terbatas, partisipan tidak dapat mendapatkan pengarahan dan tidak dapat berkonsultasi saat menghadapi masalah dalam mempraktikkan hasil pelatihan di sekolah.

\section{Kesimpulan}

Berdasarkan hasil penelitian yang dilakukan dapat disimpulkan bahwa pelatihan "INTERAKTIF" dapat meningkatkan empati guru BK SMP di Yogyakarta. Pelatihan "INTERAKTIF" disusun dari teori kecerdasan emosi dan komunikasi terapeutik, serta disampaikan melalui metode experiential learning. Pembelajaran yang diperoleh partisipan dari pelatihan "INTERAKTIF" diukur dengan skala kecerdasan emosi konselor sedangkan perubahan perilaku diukur dengan skala empati, hasilnya menunjukkan bahwa peningkatan empati pada partisipan disebabkan oleh pelatihan yang diberikan. Hal ini diperkuat oleh dengan hasil observasi yang dilakukan observer serta evaluasi dan refleksi dari partisipan, partisipan yang menilai positif pelatihan, memiliki antusiasme tinggi, dan terlibat aktif dalam pelatihan dapat memperoleh pembelajaran yang tepat dari pelatihan. Pemerolehan pembelajaran yang tepat membuat empati partisipan meningkat.

\section{Saran}

Peneliti selanjutnya diharapkan dapat mengontrol jenis kelamin dan usia partisipan, sehingga peningkatan empati yang terukur benar-benar karena pelatihan tanpa ada pengaruh dari jenis kelamin dan usia yang bervariasi. Selain itu, peneliti selanjutnya diharapkan dapat mengukur kebertahanan perubahan perilaku (follow up) untuk mengetahui seberapa lama efek pelatihan dapat bertahan.

\section{Daftar Pustaka}

Abdolvahabi, Z., Bagheri, S., Haghighi, S., \& Karimi, F. (2012). Relationship between emotional intelligence and self-efficacy in practical courses among physical educators teachers. Pelagia Research Library, 2(5), 17781784.

Afiatin, T., Sonjaya, J. A., Pertiwi, Y. G. (2013). Mudah $\mathcal{E}$ sukses menyelenggarakan pelatihan, melejitkan potensi diri. Yogyakarta : Kanisius.

Altmann, T., Schonefeld, V., Roth, M. (2015). Evaluation of an empathy training program to prevent emmotional maladjustment symptoms in social professions. Scientific Research Publishing, 6, 1893-1904. doi : 10.4236/psych.2015.614187

Ancel, G. (2006). Developing empathy in nurses: An in-service training program. Archives of Psychiatric Nursing, 20(6), 249-257.

Atamimi, N. (2010). Functional empowerment of psychological skills for guidance and counseling teachers. Book of Abstracts Presented in The First International Conference of Indigenous and Cultural Psychology. Yogyakata: CICP Fakultas Psikologi Universitas Gadjah Mada.

Aziza, A. (2015). Pelatihan ASPIRASI dapat meningkatkan kemampuan empati pada staf LAPAS. Tidak diterbitkan. Yogyakarta : Tesis Magister Psikologi Profesi Universitas Gadjah Mada.

Berkhout, E. T., \& Malouff, J. M. (2016). The efficacy of empathy training : A-meta 
analysis of randomized controlled trials. Journal of Counseling Psychology, 63(1), 32-40.

Barone, D. F., Hutchings, P. S., Kimmel, H., Traub, H. L., Cooper, J. T., Marshall, C. M. (2005). Increasing emphatic accuracy through pratice and feedback in a clinical interviewing course. Journal of Social and Clinical Psuchology, 24(2), 156-171.

Clark, A. J. (2007). Empathy in counseling and psychotherapy, perspective and practices. London: Lawrence Erlbaum Associates, Inc., Publishers.

Davis, M. H. (1983). Measuring individual differences in empathy: Evidence for a multidimensional approach. Journal of Personality and Social Psychology, 44, 113-126. doi: 10.1037/0022-3514 .44 .1 .113

DePue, M. K., \& Lambie, G. W. (2014). Impact of university-based practicum experience on counseling students' levels of empathy and assessed couseling conpetencie. Counseling Outcome Reseacrh and Evaluation, 5(2), 89-101. doi : 10.1177/2150137814548509

Fernández-Olano, C., Montoya-Fernandez, J., \& Salinas-S nchez, A. S. (2008). Impact of clinical interview training on the empathy level of medical students and medical residents. Medical Teacher, 30(3), 322-324.

Ioannidou, F., Konstantikaki, V. (2008). Empathy and emotional intelligence : what is it really about?. International Journal of Caring Science, 1(2), 118-123.

Goldstein, A. P. (1981). Psychological skill training: The structured learning technique. New York : Pergamon Press.

Goleman, D. (1998). Working with emotional intelligence. London: Bloonsbury Publishing.

Hakansson, J. \& Montgomery, H. (2003). Empathy as an interpersonal phenomenon. Journal of Social and Personal Relationship, 20(3), 267-284.
Hervina, E. (2017). Pelatihan keterampilan dasar konseling sebagai upaya meningkatkan efikasi diri staf wali di Lapas. Yogyakarta: Tesis Magister Psikologi Profesi Universitas Gadjah Mada. Tidak diterbitkan.

Johnson, D. R. (2016). Emotional intelligence and public health education: A prescriptive needs assesment. Pedagogy in Health Promotion: The Scholarship of Teaching and Learning, 2(3), 193-200. doi: $\underline{10.1177 / 2373379916630996}$

Kolb, A. Y., \& Kolb, D. A. (2009). The learning way: meta-cognitive aspect of experiential learning. Simulation $\mathcal{E}$ Gaming, 40(3), 297-327

Kur. (2016). Kenakalan remaja masuk daftar potensi ancaman di DIY. Retrieved from

http://jogja.tribunnews.com/2016/12/14 Lkenakalan-remaja-masuk-daftarpotensi-ancaman-di-diy

Lam, T. C. M., Kolomitro, K., \& Alamparambil, F. C. (2011). Empathy training: Methods, evaluation practices, and validity. Journal of Multi Disciplinary Evaluation, 7(16), 162-200.

Mayers, A. (2013). Introducction to statistics and SPSS in psychology. London: Pearson Education Limited.

Myers, A. \& Hansen, C. (2012). Experimental psychology, 7th edition. United States of America: Wadsworth Cengage Learning.

Peraturan Menteri. (2008). Peraturan Menteri Pendidikan Nasional Rebublik Indonesia Nomor 27 Tahun 2008 tentang standar kualifikasi akademik dan kompetensi konselor. Retrieved from http://bsnpindonesia.org/id/wpcontent/uploads/tenaga/Permen 27 Th-2008.pdf

Peraturan Menteri. (2014). Peraturan Menteri Pendidikan dan Kebudayaan Rebublik Indonesia Nomor 111 Tahun 2014 tentang bimbingan dan konseling pada pendidikan dasar dan pendidikan menengah. 
Retrieved

simpuh.kemenag.go.id/regulasi/perme ndikbud_111_14.pdf

Ramdhani, N., Ancok, J., Swasono, T., \& Suryanto, P. (2012). Teacher quality improvement for building better relationship between school counselor and students. Procedia Social and Behavioral Sciences, 69, 1836-1841.

Ramdhani, N. (2018). Peningkatan kompetensi guru bimbingan dan konseling untuk meningkatkan kebahagiaan siswa. Proposal Penelitian. Tidak diterbitkan. Yogyakarta: Fakultas Psikologi Universitas Gadjah Mada.

Riess, H., Kelley, J. M., Bailey, R. W., Dunn, E. J., \& Phillips M. (2012). Empathy training for resident physicians: a randomized controlled trial of a neuroscience-informed curriculum. Society of General Internal Medicine, 27(10), 1280-6. doi : 10.1007/s11606-0122063-z

Rossenberg, M. B. (2005). Nonviolent communication: A language of life. United Stastes of America: PuddlerDancer Press Book

Santrock. J. W. (2010). Adolescence, thirteenth edition. New York : McGraw-Hill.

Saleh, U. (2008). Pengaruh pelatihan mindfulness terhadap peningkatan empati perawat. Yogyakarta: Tesis Magister Psikologi Profesi Universitas Gadjah Mada. Tidak diterbitkan.

Sari, T. R. (2010). Persepsi siswa terhadap guru bimbingan konseling di Madrasah Aliyah Negeri Sidoarjo. Surabaya: Skripsi Fakultas Dakwah Institut Agama Islam Negeri Sunan Ampel Surabaya. Tidak Diterbitkan.
Shadish, W., Cook, T. D., \& Campbell, D. T. (2002). Experimental and quasiexperimental design for generalized causal inference. Boston : Hounghton Mifflin Company.

Sulistyaningsih, W. (2009). The impact of resience training and elucidation in reducing psychological trauma and increasing empathy in south aceh regency (pengaruh pelatihan resiliensi dan penyuluhan untuk menurunkan trauma psikologis dan meningkatkan empati pada guru di kabupaten aceh selatan). Tidak diterbitkan. Yogyakarta : Disertasi Doktor Fakultas Psikologi Universitas Gadjah Mada.

Vanlaere, L., Coucke, T., \& Gastmans, C. (2010). Experiential learning of empathy in a care-ethics lab. Nursing Ethics, 17(3), 325-336. doi : $\underline{10.1177 / 096973310361440}$

Wardhani, N. (2009). Keterampilan konseling guru pembimbing: studi deskriptif mengenai keterampilan konseling yang menunjang tujuan hubungan konseling pada guru pembimbing di SMA " $Y$ " Bandung. Tidak diterbitkan. Bandung : Laporan Penelitian Fakultas Psikologi Universitas Padjadjaran.

Widhiarso, W. (2011). Aplikasi ANAVA campuran untuk desain eksperimen prepost test design. Yogyakarta: Fakultas Psikologi Universitas Gadjah Mada.

Wulandari, S., Setyowati, N., \& Mugiarso, H. (2012). Upaya meningkatkan empati dalam berinteraksi sosial melalui dinamika kelompok pendekatan experiential learning. Indonesian Journal of Guidance and Counseling : Theory and Application, 1(2), 40-46. 